\title{
WHY SUBALTERN LANGUAGE? YES, WE SPEAK Portuguese! For a Critique of The Coloniality of LANGUAGE IN INTERNATIONAL STUDENT MOBILITY
}

\author{
Rovênia Borges \& Almerindo Janela Afonso
}

\begin{abstract}
The ability to communicate in English is often associated with the condition of social class, gender and other factors of cultural identity. In this early $21^{\text {st }}$ century, it has become one of the main constraints to participate in study and research programs in universities with top academic rankings. However, in many countries with too many educational inequalities, namely in Portugal and Brazil, the hegemony of the English language is a worrying factor for the internationalisation policies aimed at the high qualification of researchers in several scientific areas, especially those that lead to innovation and bring added value to the knowledge economy. From a comparative perspective, and taking into account some assumptions of postcolonial critical theories, this article presents a critical reflection on how English language teaching policies in the countries mentioned have acted to reinforce inequalities in terms of international student mobility.
\end{abstract}

\section{Why subaltern language? Yes, We speak Portuguese! PARA UMA CRÍTICA DA COLONIALIDADE DA LÍNGUA NA MOBILIDADE ESTUDANTIL INTERNACIONAL}

\begin{abstract}
RESUMO
Comunicar fluentemente em língua inglesa, possibilidade vulgarmente associada à condição de classe social e à posse de outros bens posicionais, tornou-se uma das principais vantagens competitivas para participar de programas de estudo e de pesquisa em universidades bem localizadas nos rankings académicos. A nível mais geral, face às desigualdades sociais e educacionais, nomeadamente em Portugal e no Brasil, a hegemonia da língua inglesa constitui um obstáculo para os países de língua portuguesa que investem em políticas de internacionalização para a qualificação avançada de pesquisadores em áreas científicas, nomeadamente naquelas que induzem inovação e trazem mais-valias para a economia do conhecimento. Sob perspetiva comparada, e tendo em conta alguns pressupostos das teorias críticas pós-coloniais, este artigo faz uma reflexão sobre como as políticas da língua inglesa nos países acima referidos contribuem para reforçar desigualdades e desvantagens para muitos candidatos a programas de mobilidade científica internacional.
\end{abstract}

\section{Palavras-Chave}

Língua inglesa; Brasil/Portugal; internacionalização; desigualdades; colonialidade 


\section{UNDER THE COLONIALITY OF THE LINGUA FRANCA OF KNOWLEDGE}

Despite the previous economic, cultural and military power of the British Empire, it was after World War II that English reached the predominance that it has today as a linguistic vehicle supporting the multiple international interactions. Indeed, as the conflict ended, and in the condition of "victorious", the USA and England adopted strategies, which even disputed and contestable, have been effective to build and maintain the current hegemony of the English language. Not indifferent to this was the acceleration of the dynamics of globalisation, which has strongly contributed to the fact that English keeps assuring itself as a lingua franca' in international relations (political, economic, commercial, scientific, cultural, educational...), becoming also a dominant vehicle of exchange and collaboration in (and between the) various higher education institutions and research centres in different countries.

As a corollary of its broadened irradiation on a global scale, English today extends to different dimensions of social life, many of which are impregnated with a Euro(north) American hegemonic vision, generically referable to the coloniality of power - an expression used by the Peruvian sociologist Aníbal Quijano (2002, p. 4) to refer to a matrix, or "global pattern of power" ${ }^{2}$, which includes as articulated constitutive elements the forms of domination by racialized social stratification, by the capitalist exploitation of labour and by the Euro(north)American ${ }^{3}$ way of producing scientific and technological knowledge.

For authors of Latin American postcolonial studies, coloniality expanded, especially from the sixteenth century, with the arrival of the Iberian conquerors to the Americas, initiating the proselytising and violent inculcation of religious beliefs, and imposing other languages, cultures and visions of the world, (self)justified by the supposed supremacy of the nascent European modernity. From then on, the colonial matrix of power that was under the leadership of Portugal and Spain between 1500 and 1750, developed in the Catholic-Iberian phase of modernity and domination of the most profitable mercantile route of the globe, the South Atlantic (Barrantes-Monter, 2018, p. 10). However, from the eighteenth century onwards, with the economic rise of England, France and Germany over southern Europe, as living languages of two declining Iberian empires, Portuguese and Spanish gradually began to lose strength.

But regardless of this change in colonial power relations, the fact is that after the (formal or conventional) end of European colonialism, its ideological legacies and its

\footnotetext{
"Lingua franca means that the language is used "as a contact language among speakers from different first languages" (Jenkins, 2015, p. 56). This role was already played by Latin, which was the cultured and socially prestigious language taught until approximately the XVI-XVII centuries, when it was gradually replaced by the "lingua franca of the Discoveries and subsequent imperialist powers" (Martins \& Cardoso, 2015, p. 141).

${ }^{2}$ Walter Mignolo (2010, p. 12) adds that the colonial matrix is a complex structure of distinct levels of coloniality of power intertwined in order to gain control of the economy, authority (State), nature and natural resources, gender and sexuality, subjectivity and knowledge (way of thinking and producing knowledge).

${ }^{3}$ According to Silva Júnior (2017, p. 14), since the mid-199os, both European universities, with the Bologna Process, and Brazilian universities, with the neoliberal policy adopted in the governments of Fernando Henrique Cardoso, have undergone a "process of significant mutation towards the Anglo-Saxon model under the hegemony of the American version". Therefore, instead of Eurocentrism we chose to update the term Euro(north)American, inspired by Quijano.
} 
cultural instruments of oppression continued to interfere strongly in social relations in Brazil and other countries, including Latin American and African. Outside of the historical period of colonialism, but still marked by the coloniality of power, English continues to consolidate itself as a lingua franca of the production and dissemination of technical and scientific knowledge in different areas, functioning also, and increasingly more so, as an instrument of construction of new subjectivities and new cognitive ways of perceiving and interpreting the world. According to Robert Stam, "in the international division of intellectual work", the trend that has been maintained, since the beginning of historical modernity, is that of the growing cultural and scientific Eurocentric domain, (supposedly) more advanced than other knowledge and cultures, exalting "the thinkers of the Global North to the detriment of the thinkers of the Global South" (Stam in an interview with Santos \& Schor, 2013, p. 703).

Also in the last three decades, the hegemony of the English language has become one of the mainstays of the (capitalist) internationalisation boom of higher education. Among other reasons, the more intense flow of students crossing national borders can be explained not only by the new opportunities opened by globalisation, but also because many families, especially the new middle classes, are betting on the internationalisation of their children's studies (Nogueira, 2017) and "often believe overseas qualifications to be more valuable than 'local' ones" (Lasanowski, 2013, p. 199). As a result, international student routes are predominantly focused on institutions offering courses in English, with the most prestigious ones being (or seeking to be) the best places in world rankings.

Data available online at the official Unesco Institute for Statistics (2018) website point to the United States and the United Kingdom as the countries that most recruit international students ${ }^{4}$. Apart from the reciprocal mobility between these countries, it is also noted that, from them, the options also go towards other Anglophone capitalist countries ${ }^{5}$. With regard to international mobility routes to Brazil, this statistical survey indicates the demand for this country by 19.855 students from 199 different nationalities, the most significant being Angola (2.317), Colombia (1.627), Peru (1.409), Paraguay (1.082) and Argentina (1.061). Portugal comes in eighth, with 806 international students and the United States, in tenth, with 663 Americans $^{6}$ ). Conversely, Brazil sent more than twice as many students abroad (43.438), with the United States as the main destination with 13.349, followed by Portugal with 6.372 students, France with 4.311 , Germany with 3.790 and the United Kingdom with 2.713.

\footnotetext{
${ }_{4}^{4}$ According to the online map of Unesco Institute for Statistics 2018 (Global Flow of Tertiary-Level Students), consulted on 30 April 2018 , the US received 907.251 international undergraduate and graduate students who studied abroad for a period of at least one year, 291,063 from China, 112,714 from India and 63.952 from South Korea. In the reverse flow, it sent 68.580 students to study abroad, with the UK being the main destination (15.378), followed by Canada (8.355) and Grenada, in the Caribbean (4.543). The United Kingdom, in turn, accommodated 430,687 international students, mostly Chinese (91.518), Indians (18.177) and Nigerians (17.881). In reverse mobility, the main destinations were the USA (9.601), Australia (2.019), France (1.995), Germany (1.798).

${ }^{5}$ Of the first three destinations for international mobility of US students, $41,1 \%$ were English-speaking countries: The United Kingdom, Canada and Grenada. The United States ranked as the main host country for students in the UK, accounting for $29 \%$ (Unesco Institute of Statistics, 2018).

${ }^{6}$ Data referring to Brazil are from 2015 (Unesco Institute for Statistics, 2018).
} 
In the analysis of international mobility restricted to Portugal7, there was a slightly higher flow of students received (16.888) than those sent abroad (12.335). The main country of origin of international students was Brazil (6.372), followed by Angola (2.761). These data show that $54 \%$ of international students attending higher education institutions in Portugal are Portuguese speakers and come from their two largest ex-colonies. On the other hand, Brazil and Angola are not among the main destination countries of the Portuguese, who choose to study in the United Kingdom (2.709) and France (1.857), followed by Spain (1.586) and the United States (887). Brazil appears only as the fifth preferred destination (806).

There is of course a combination of factors influencing the design of the routes, such as the economic condition of students, geographic or historical-cultural proximity between countries, climate and safety factors, and the induction of world rankings ${ }^{8}$ of universities. However, we cannot but consider a new form of coloniality of power moulded in the world map of international mobility, using the hegemony of English for access to scientific and technological centres of excellence in the United States, United Kingdom ${ }^{9}$, Canada, Australia, as well as reference institutions located in non-English speaking countries, such as Germany, which started to offer courses in English as a commercial recruitment strategy (Lasanowski, 2013, p. 204), that is, as an "export business" (Holford, 2014, p. 22).

In the Americas, the "power" to attract international students is, according to Unesco statistics, heavily concentrated in the United States and the revenue generated from this mobility is "intrinsically linked to national, regional and state economies" (Spears, 2014, p. 155). As a result, the United States and the United Kingdom stand out as the most popular destinations on the world map of mobility routes, becoming a sort of Knowledge Mecca where "three in every ten overseas students currently flow" (Lasanowski, 2013, p. 195).

However, the United States and the United Kingdom do not emerge as countries that send more students abroad, a position occupied by China, India and Germany'o. From this perspective, as can be seen, the international mobility routes show many imbalances. Even among countries with semi-peripheral positions in the world context, the two directions of the same mobility route are quite asymmetrical. Although Brazil and Portugal had the United States and the United Kingdom largely as host countries of their mobility programs, only $1,3 \%$ of US students and $0,7 \%$ of British students chose to study

\footnotetext{
7 Data referring to Portugal are from 2016 (Unesco Institute for Statistics, 2018).

${ }^{8}$ Regarding the factors influencing the mobility of Portuguese students, despite the financial support of the European Union with the granting of scholarships, "the cost of living and geographic distance are still relevant to explain student flows between countries" (Cunha \& Santos, 2017, p. 56).

9 Since the Bologna Process, at the turn of the century, universities and the UK government are engaged in recruiting students from outside Europe, with tuition paid by students an important source of revenue - the value is around 11 thousand euros per year, the "highest in the European Union" (Viana, 2018, p. 14).

${ }^{10}$ Among the countries that most accommodated international students are the United States (907.251), followed by the United Kingdom (430.687) and Australia (335.512), all English speakers. China (847.259), India (278.383) and Germany (117.921) have the largest number of students abroad (Unesco Institute for Statistics, 2018).
} 
in Brazilian and Portuguese institutions. In the opposite direction, $38 \%$ of Brazilians and Portuguese went to US-based teaching and research institutions and $28 \%$ to the United Kingdom (Unesco Institute for Statistics, 2018).

This last trend does not in any way reveal that Brazilian and Portuguese universities, like those of many semi-peripheral and peripheral countries in the perspective of the world economy, are far from accepting any other alternative than subordination to the premises of a scientific-technical epistemological Euro(north)American coloniality. We are trying to critically understand the "emerging dark side at university", which translates a rupture with its ethos as a modern institution based "on a broad ethical, educational and cultural vision" for a business-like organisation that is increasingly guided by "spurious interests of capitalism, increasingly internationalized" (Afonso, 2017, p. 8). Given the fact that student mobility occurs predominantly on this side of the abyssal line of thought (to use Boaventura Sousa Santos's expression), in this current phase of epistemic hegemony in the North, the scientific knowledge produced by the central countries is inevitably the most wanted. In this sense, from our point of view, the break with the current standards of international mobility in the field of study and research can only occur when many countries stop being just consumers and become also producers of advanced scientific and technical knowledge and/or when the value of other knowledge and epistemologies ("epistemologies of the South") is recognized, for what is necessary "a struggle for global cognitive justice [that] to succeed requires a post-abyssal thought" (Santos, 2009, p. 32).

Paradoxically, in semi-peripheral countries like Portugal and Brazil, one of the criticisms to university is that it continues to be delayed precisely because it does not follow the supposedly more advanced standards of other countries. In this regard, one author (ex-chancellor) writes: "putting Brazil in the educational landscape of the world is the responsibility of the university. For this, it is imperative that, in the complex relations of international exchanges, we have educational systems that are valued and compatible with the intellectual and economic centres of the contemporary world" (Almeida Filho, 2008, pp. 179-180). However, as Edgardo Lander points out, this reaction must take into account "the ideological process of the naturalisation of the market society" in which the very production of "thought is not distinguished from propaganda" (Lander, 2015, pp. 46-55).

In our opinion, a critical reflection that calls into question the universities of the Global South must be made aware of the current processes of globalisation with regard to the production of knowledge" ${ }^{11}$. We are not here to oppose internationalisation in higher education, but to draw attention to the fact that, in the present historical conditions, the profound asymmetries in scientific mobility (of students and researchers) do not leave some way of perpetuating (and even reinvigorate) neocolonial relations of domination and injustice. Under this perspective, in line with what postcolonial Latin American authors call decolonise universities, we believe it is possible to (also) encourage the

\footnotetext{
"Bearing in mind the "specificities of capitalism" of the central countries and their advance on institutions of higher education in semi-peripheral economies, we can see in the wake of Silva-Júnior's study (2017, p. 251) the construction of "new Portuguese and Brazilian universities".
} 
search for alternative routes of internationalisation that do not rely on the mere hypervaluation of individual projects and strategies for an insertion more advantageous in the new financial and cognitive capitalism, but that mobilise collective projects, namely in the search for scientific, technical, cultural and educational solutions to the problems that capitalism itself is not able to solve. These alternatives also have to be accompanied by the breakdown of the monopoly of the English language, because "monolingualism (English language) is claimed to be the condition for modernization, while multiplicity of languages is rather a nuisance" (Barrantes-Montero, 2018, p. 5).

Allied to what this means and implies, we can also reflect on the paradox of the phenomenon of internationalisation, which, at the same time, is enlarged by an expanded demand, involving students of linguistic cultures from all over the world, to the imperative of the lingua franca of the global economy. Thus, the globalisation of the English language also implies its popularisation, which may in the future lead to the valuation of other languages for the purposes of student mobility and the labour market. According to Veronica Lasanowski (2013, p. 205) "future employers will increasingly seek more global (i.e. multilingual) graduates in the longer term, providing the opportunity to learn in more than one language or to study in English in a non-English context grow comparably more popular".

By this bias, universities with courses in English, but not English speakers, compete with the United States and the United Kingdom for international students interested in becoming fluent in a second foreign language. For the British linguist, Jennifer Jenkins, this tendency leads to the construction of a truly international university because it adopts English as a lingua franca, but also configures itself in a multilingual space, which means teaching in a variety of languages. However, according to the author, in Anglophone universities, even before all the rhetoric of diversity, "the prevailing ethos remains the outdated one of acculturation, the diametric opposite of a multilingual approach" (Jenkins, 2015, pp. 78-79). Thus, the universities of English-speaking countries that attract the most international students end up perpetuating the "monolingual culture" and prevent them from benefiting from the "rich linguistic and cultural resources that international students bring with them" (Jenkins \& Wingate, 2015, p. 48).

\section{FROM NEGLIGENCE TO URGENCY: THE ENGLISH LANGUAGE TEACHING POLICY}

Over the past decade, political strategies in Brazil and Portugal have focused heavily on the internationalisation of higher education. Both lusophone countries, which are positioned as semi-peripheral countries in the world economic system, invest in and implement mobility programmes in the expectation of strengthening their education and research institutions, as well as gaining advantages in the international higher education market. Thus, as of 2014, besides the existing Erasmus programme, Portuguese polytechnic higher education institutions and universities started to accept Brazilian students who achieve good grades in national exams administered by the Brazilian Ministry of Education to secondary education graduates. In turn, in Brazil, internationalisation 
gains political relevance with the Ciência sem Fronteiras [Science without Borders] Programme, established in 2011.

In both settings, mobility follows a path that is in tune with the requirements of the knowledge economy, in a global regulation pattern in which universities and research centres are qualified by outcome indicators. Along with numbers that measure scientific publications, specialised services and patents, the presence of international students is among the academic excellence ranking criteria in a worldwide comparison (Marginson, 2017, p. 7). Therefore, besides being a key source of revenue, the influx of students seeking international education represents points for the positional status of such institutions in the main worldwide rankings. It is not by chance that the offering of courses and curriculum units taught in English also justifies the imperative of strengthening the competitiveness of the European higher education area.

Thus, Brazilian and Portuguese internationalisation policies must be perceived in its particularities (which sometimes are antagonistic), although they are interwoven into a hegemonic global agenda where a highly profitable education market is under development. According to Terri Kim (2009, p. 398), we are in the face of a cross-border mobility that contributes to the corporatisation ${ }^{12}$ of university on a global scale. Hence, the problematisation of this context, in light of the coloniality concept, cannot be avoided, since the formal education valued is the hegemonic one and, therefore, it is "supported and financed by both domestic and international structures of power with a clear interest in maintaining the educational system as an instrument of keeping control of production means and dynamics" (Barrantes-Monteiro, 2018, p. 3). This is consequently a relationship between political and economic forces which, in the recent internationalisation of higher education in Brazil and Portugal in particular, has been revealed to be aligned with the neoliberal globalisation agenda.

Recent changes in educational policies for English language teaching illustrate well what we are problematising. As we have seen, English proficiency became part of the "international skill set" required for job opportunities in "globally oriented firms" (Lasanowski, 2013, p. 197) 13. As a result, the speaking competence has (also) been emphasised in educational policies of both lusophone countries. In Brazil, at the height of the

\footnotetext{
${ }^{12}$ The author uses the term "corporatization", recurrent in the administration/management of big private companies (corporations) to allude to contemporary public management. In parallel, in the field of public education, Terri Kim notes that the adoption of a new governance and management model for universities in the United Kingdom prioritises the "efficient management" of resources in higher education and leads to the creation of a new "top-down line management structure". "This has led to the changing nature of the academic profession. University academics are increasingly evaluated through quantitative business-driven procedures" (Kim, 2009, p. 397). And she further states that: "overall, it is suggested that the contemporary condition of transnational academic mobility is mostly framed by 'economic globalization', and the neoliberal market regime has resulted in the rise of corporatist governance and management in the $\mathrm{HE}$ sector in countries like New Zealand, Australia and the UK" (Kim, 2009, p. 399).

13 "This argument, that the ability to speak English is highly conducive to future employment opportunity, goes even further toward explaining the attractiveness of the English-speaking destinations" (Lasanowski, 2013, p. 197). Further on, the author adds: "given that students often believe overseas qualifications to be more valuable than 'local' ones, the fact that the United States, the United Kingdom, Australia, Canada, and New Zealand provide quality, internationally recognized qualifications is a prime motivational factor "pulling' international students toward them" (Lasanowski, 2013, p. 199).
} 
neoliberalism in the 1990s, speaking was not valued by language policy ${ }^{14}$. It was understood that "only a small portion of the population [had] the opportunity to use foreign languages as an oral communication instrument, within the country or abroad" (MEC/ SEF, 1998, p. 20). Vera Lúcia Menezes de Oliveira Paiva (Amorim, 2015), a Brazilian researcher, criticises this elitist point of view on English language teaching in Brazilian schools and states that, by disregarding the social relevance of writing and speaking skills, the policy reinforced the discrimination against low income classes, which only relied on public school to learn a second language.

The turning point in language teaching policy in Brazil occured in the early 2000s, along with education reforms demanded by the global economy ${ }^{15}$. Since then, the internal coloniality exerted by the ruling elite in Brazil - and which hindered the access of the poorest people to international education through poor foreign language teaching - is defeated by an external coloniality, to impose the hegemony of English in order to operationalise the higher education capitalist internationalisation machine. Nearly in the blink of an eye English ceased being a secondary subject to figure among the subjects that have superior status. However, there was no time or impulse in the public budget to surmount the obstacles and overcome the historical negligence for quality English language teaching in Brazilian schools. The implementation of the Science without Borders Programme in December 2011 faced this problem to the extent that the establishment of adjacent policies to improve university students' English proficiency, namely speaking and writing skills for internationalisation purposes, became urgent ${ }^{16}$.

In Portugal, innovations in the guidelines on English language teaching occurred slowly and the valuation of communicative competences can be understood in the context of the Common European framework of reference for languages, of 2001, considering "the challenges of intensified international mobility and closer co-operation not only in education, culture and science but also in trade and industry" (Council of Europe, 2001, p. 22). In order to do so, and also according to the document, education policies in Europe need to be organised into common teaching-learning levels to meet the needs of a "multilingual" and "multicultural" Europe. For this reason, after the publication of CEFR, besides English, a second foreign language became part of the school curriculum and "both oral interaction and oral production started to be part of the abilities that gained greater relevance" on the agenda of language teaching policy in Portugal (Martins \&

\footnotetext{
${ }^{14}$ In Brazil, foreign language teaching was historically a secondary subject in school curriculum. It was only after the approval of Provisional Decree 746 of 2016, which amended Law 9.394/1996 - the Law of Guidelines and Bases of Brazilian Education (LDBEN), that it became a mandatory curriculum unit starting from the $6^{\text {th }}$ school year. Before this, it was mandatory to offer one foreign language, but not necessarily English.

${ }^{15}$ The Curriculum Guidelines for Secondary Education (OCEM), from the Brazilian Ministry of Education, in the third chapter, focused on "Languages, Codes and its Technologies", provide a specific section for foreign language teaching in which the importance of being proficient in a foreign language is problematised, given the "exclusion in education in the face of 'globalizing' values and the sense of belonging", commonly associated with the command of a language (MEC/SEB, 2006, p. 87).

${ }^{16}$ The low proficiency of students who apply for Science without Borders was revealed to be the greatest challenge to achieve, in a four-year period, the goal of granting 100.000 scholarships. The Brazilian Ministry of Education felt pressured to institute the Inglês sem Fronteiras [English without Borders] programme, with the purpose of fostering university students' education and training for proficiency tests required for entering Anglophone universities (Borges, 2018, p. 2).
} 
Cardoso, 2015, p. 140)17. In brief, English language teaching policy in Portugal aims to achieve "a more rigorous level of proficiency, more aligned with the existing international referential frameworks" (Decree-law No. 176, 2014, p. 6065).

\section{Portuguese, A SUbALTERn LANGUAGe IN GLOBAL STUdeNT MOBILITY}

In the increasing global student mobility, English communication competence became a primary condition for participating in study and research programmes in universities that hold the highest positions in academic rankings, "the lighthouse of Alexandria", according to João dos Reis Silva Júnior (2017, p. 255). However, based on empirical research data, we argue that this competence may be revealed to have more or less impact on international mobility policies, depending on the combination of inequalities. In addition, these factors combined can shape potential routes, which are not always desirable, for the most disadvantaged social groups. With an emphasis on English language proficiency and teaching, we present the following preliminary analysis comparing Brazil and Portugal.

While middle class students represent a significant portion of students in Portuguese public schools - unlike in Brazilian public schools - still "a meaningful number of students enter higher education with major gaps at the speaking competence level" (Martins \& Cardoso, 2015, p. 150) concerning English language proficiency. In Portugal, the Educational Evaluation Institute (IAVE) of the Ministry of Education and Science established a protocol with the University of Cambridge in 2013 for English level external evaluation tests in Portuguese basic education schools. The objective set by the government targeted the achievement of Br proficiency level by the end of the $9^{\text {th }}$ grade (ability to communicate on simple topics of the daily routine) as recommended by CEFR. English language tests applied in Portuguese schools during 2014 and 2015 showed worse results for speaking competences: $66 \%$ and $64 \%$ of $9^{\text {th }}$ grade students had a performance considered "weak" or "borderline", respectively, on reading Q 2 writing and listening components (Sousa et al., 2014, p. 11).

These data and the path pursued thus far have led us to reflect on the extent to which English language proficiency is restricting the mobility of Portuguese students to elite universities based in Anglophone countries. Naturally, beyond the issue of English language proficiency, other factors, namely economic ones, influence the choice of destination. Among 33 European countries participating in the Erasmus+ Programme, which is financially supported by the European Union, Spain and Italy have been the two main host countries for Portuguese students. In 2015, these countries were chosen by $34.1 \%$ of those who took part in the European mobility programme. In turn, the United Kingdom

\footnotetext{
${ }_{17}$ As of 2007, with Administrative Rule no. 1322, the assessment of speaking became mandatory for foreign languages, representing $30 \%$ of the grade. According to Martins and Cardoso (2015, p. 140), until then, speaking in Portuguese classrooms, whether in production or in comprehension, had "very little (or no) weight at the level of the methodological approach". In relation to English, since the $2015 / 2016$ school year, with the issuance of Decree-law no. 176/2014, the teaching of this subject was anticipated by two years and became mandatory in the curriculum of Portuguese schools starting from the 3 rd grade of school. Therefore, in Portugal, English teaching adds up to ten consecutive years until the end of secondary school, three years more than in Brazil.
} 
ranks as the sixth country on the list, with $4,6 \%$ of the total number of students. The inverse flow is shown to be quite balanced, with Spain and Italy together accounting for $35,5 \%$ of their students received in Portugal. The United Kingdom, however, ranks $13^{\text {th }}$, in a remote position, with only $1,7 \%{ }^{18}$ (European Union, 2017).

In Brazil, the English language proficiency of students who enter universities has already shown to be an issue for internationalisation programmes, although the United States is the main academic mobility destination. The analysis of a sample comprising 1.283 Science without Borders (CsF) Programme participants, who took up part of their undergraduate studies in American institutes between 2012 and 2015, reveals that proficiency is closely associated with gender, race, social class and past academic history (public or private school) variables. Conversation was the least proficient competence among the analysed competences, namely among female, black, poorer students and those who studied at public schools, which, in general, have poorer education quality in Brazil (Borges, 2018, pp. 129-132). Then, the extent to which Brazilian society inequalities reflected on the mobility to the United States - the country that received most Science without Borders participants - was verified. Close to $60 \%$ of the students stated that they took an English language course for up to 16 weeks in said country in order to "improve language proficiency" (Borges, 2018, p. 134).

These data are relevant because they expose how social phenomena driven by the globalisation of education are pervaded by a complex network of power relations and interact with social factors to perpetuate and magnify injustice and inequalities in different societies. In the Science without Borders programme, for instance, the absence of a language barrier in Portugal for international students from Brazil can explain, to a large extent, the reason why Portuguese higher education institutions became the only option for many students. This possibly explains why the Brazilian government, faced with a high number of candidates, has discontinued the mobility to Portugal under the argument that the programme also aimed to improve foreign language proficiency. As a result of this action, "the partnership with the Conselho de Reitores das Universidades Portuguesas [Council of Rectors of Portuguese Universities] (CRUP) has been put aside to the detriment of Anglophone partners in particular" (Borges \& Garcia-Filice, 2016, p. 9). Students who were transferred to the USA claimed to have chosen Portugal because of the difficulty with the English language (Borges \& Afonso, 2017, p. 82):

the language course represents a big step to obtain the scholarship because, if you are proficient in English, you can apply to scholarships to several countries, for example. This was not my case, since I wasn't proficient in any language and had applied to study in Portugal. (Interviewee 1)

\footnotetext{
${ }^{18}$ Went to study in Spain and Italy 1.882 and 1.070 Portuguese students, respectively. The United Kingdom received 386 Portuguese students in 2014. In the opposite flow direction, Portugal received 2.655 Spanish students and 1.822 Italian students. The United Kingdom sent 219 students to Portuguese institutions in 2015 through the Erasmus+ Programme. In Europe, the main destination for British and Northern Irish students is France, which received 24,8\% Erasmus+ participants. Portugal ranked in the $15^{\text {th }}$ position, being the choice of $1,2 \%$ of 31.067 students from the United Kingdom who participated in the programme (table ANNEX 13 - KA 103, European Union, 2017, pp. 32-33).
} 
In my case, I was relocated to the USA, because I actually had applied for a scholarship to study in Portugal. Thus, I wouldn't be able to apply for a scholarship to the USA if it wasn't for this relocation of students to other countries, since I never had the opportunity to take an English course. (Interviewee 2)

Even though the United States is the main destination for Brazilian students, Portugal always ranks in the next position in official statistics ${ }^{19}$. Therefore, if on the one hand Portuguese seems like a subaltern language in the hegemonic education globalisation dynamics, on the other hand, it is presented as a counter-hegemonic option for groups of less socially privileged students who make themselves visible on international mobility routes. In the face of a setting of extreme inequalities for the acquisition of foreign languages abilities, for many Brazilian students, as well as for students from other former Portuguese colonies, Portugal is the knowledge metropolis they can reach. Consequently, children of privileged social groups, with higher economic capital and culture capital (for which the fluency in English is an indicator), end up having higher chances of acquiring the status of international student and attend universities ranked in good positions of global rankings, mainly in the USA and the United Kingdom.

A crucial question that must be posed is to know whether it is possible to have public policies fostering international mobility in a fairer and more equal way. The path can be found somehow in the way we answer the title of this article, inspired by the postcolonial thinking of the Indian theorist Gayatri Spivak (1988) - Can the subaltern speak? It served as a ground to problematise the inequalities that were perpetuated and made invisible by the English language hegemony in the global student mobility dynamics. We have indicated the impossibility of developing critical thinking about the consequences of the knowledge capitalist economy without calling into question the coloniality of power/knowledge which, as far as we could analyse, is revealed to be intertwined with new ways of dominating, exploiting and producing inequalities.

Translation: Fernanda Moreira Ferreira and Ivy Midori Kavata Ferreira

Translation revision: Língua Franca, Lda.

\section{ACKNOWLedgements}

This work is funded by CIEd - Research Centre in Education, projects UID/ CED/1661/2013 and UID/CED/1661/2016, Institute of Education, University of Minho, through the national funds of FCT/MCTES-PT [Foundation for Science and Technology/ Ministry of Science, Technology and Higher Education].

\footnotetext{
19 Taking the different international mobility modalities of Brazil as a reference, Portugal "becomes the fifth most popular country, likely because we share the same language" (CAPES, 2017, p. 45). Nevertheless, unlike in Portugal, where mobility occurs from the undergraduate level, namely with Erasmus+, in Brazil, after Science without Borders' decline in 2016, the focus is on graduate studies. In spite of this, a study with 312 Brazilian higher education institutions, published by the Ministry of Education in October 2017, classifies "Portugal in second position with only $1 \%$ less than the USA percentage of (graduate studies) scholarship requests in 2016" (CAPES, 2017, p. 13).
} 


\section{REFERENCES}

Afonso, A. J. (2017). Prefácio. Da universidade à commoditycidade: mudança ou metamorfose na educação superior? In L. Bianchetti \& V. Sguissardi (Eds.), Da universidade à commoditycidade: ou de como e quando, se a educação/formação é sacrificada no altar do mercado, o futuro da universidade se situaria em algum lugar do passado (pp. 7-12). Campinas: Mercado de Letras.

Almeida-Filho, N. (2008). Universidade nova no Brasil. In B. de S. Santos \& N. Almeida-Filho, A Universidade no século XXI: para uma universidade nova (pp. 79-184). Coimbra: Almedina/CES.

Amorim, R. (2015, 10 de junho). "É preciso investir na formação dos professores" [Interview Vera Lúcia Menezes de Oliveira e Paiva]. Jornal do Professor. Retrieved from http://portaldoprofessor.mec.gov.br/ noticias.html?idEdicao $=129 \&$ \&dCategoria $=8$

Barrantes-Monteiro, L. G. (2018). Phillipsons's Linguistic Imperialism Revisited at the light of Latin American Decoloniality Approach. Revista Electrónica Educare, 22(1), 1-19. DOI: 10.15359/ree.22-1.1

Borges, R. A. (2018). Do Brasil aos EUA: a barreira do inglês na mobilidade de estudantes. Um estudo sobre identidades e desigualdades refletidas no Programa Ciência sem Fronteiras. Berlin: Novas Edições Acadêmicas.

Borges, R. A. \& Afonso, A. J. (2017). Brasil e Portugal: a mobilidade estudantil no espaço da internacionalização. In G. S. Carvalho \& M. L. Dionísio (Eds.), Encontro Nacional de Jovens Investigadores em Educação - Livro de Resumos do II ENJIE (pp. 79-84). Braga: CIEd e CIEC.

Borges, R. A. \& Garcia-Filice, R. C. (2016). Entre Portugal e Estados Unidos: o impacto das desigualdades em duas rotas do Programa Ciência sem Fronteiras. In Portugal, Território de Territórios - Livro de atas do IX Congresso Português de Sociologia. Lisboa: Associação Portuguesa de Sociologia. Retrieved from http:// www.aps.pt/ix_congresso/actas

Conselho da Europa. (2001). Quadro europeu comum de referência para as línguas: aprendizagem, ensino, avaliação. Porto: Edições ASA. Retrieved from http://www.dge.mec.pt/ quadro-europeu-comum-de-referencia-para-linguas

Coordenação de Aperfeiçoamento de Pessoal de Nível Superior - CAPES. (2017). A internacionalização na Universidade Brasileira: resultados do questionário aplicado pela CAPES. Brasília: Diretoria de Relações Internacionais da CAPES/MEC.

Cunha, A. \& Santos, Y. (2017). Erasmus'30. A história do programa e a participação dos estudantes portugueses. Lisbon: Letras Errantes/Bookbuilders.

Decreto-Lei no ${ }^{176 / 14}$. (2014). Inglês como disciplina obrigatória a partir do $3^{\circ}$ ano. Diário da República, $1^{a}$ série, 240, 6064-6068. Ministério da Educação e da Ciência.

European Union. (2017). ANNEX 13 - KA 103 - Higher Education mobility within programme countries Students by sending/receiving country - Call 2015. Annual Report 2016. Statistical Annex Erasmust. Enriching lives, opening minds. Brussels: European Commission.

Holford, J. (2014). The lost honour of the social dimension: Bologna, exports and the idea of the university. International Journal of Lifelong Education, 33(1), 7-25. DOI: 10.1080/02601370.2013.873210

Jenkins, J. (2015). Repositioning English and multilingualism in English as a Lingua Franca. Englishes in Practice, 2(3), 49-85. DOI: 10.1515/eip-2015-0003

Jenkins, J. \& Wingate, U. (2015). Staff and students' perceptions of English language policies and practices in 'international' universities: a case study from the UK. Higher Education Review, 47(2), 47-73. 
Kim, T. (2009). Transnational academic mobility, internationalization and interculturality in higher education. Intercultural Education, 20(5), 395-405. DOI: 10.1080/14675980903371241

Lander, E. (2015). Conocimiento para que? Conocimiento para quién?Reflexiones sobre la universidad y la geopolítica de los saberes hegemónicos. In Z. Palermo, S. Castro-Gómez, E. Lander, W. Mignolo, R. Segato \& C. Walsh, Des/decolonizar la universidad (pp. 41-67). Ciudad Autónoma de Buenos Aires: Del Signo.

Lasanowski, V. (2013). Can speak, will travel: the influence of language on global student mobility. In R. Bhandari \& P. Blumenthal (Eds.), International students and global mobility in higher education (pp. 193209). New York: Palgrave Macmillan.

Marginson, S. (2017). Do rankings drive better performance? International Higher Education, 89, 6-8. DOI: $10.6017 /$ ihe.2017.89.9762

Martins, C. S. \& Cardoso, M. N. (2015). Let's talk, shall we? A oralidade no ensino do inglês em Portugal. Saber Q Educação. Perspetivas Didáticas e Metodológicas no Ensino Básico, 20, 138-158.

Mignolo, W. (2010). Desobediência epistémica: retórica de la modernidad, lógica de la colonialidad y gramática de la colonialidad. Buenos Aires: Ediciones Del Signo.

Ministério da Educação. (1998). Parâmetros curriculares nacionais. Terceiro e quarto ciclos do ensino fundamental. Língua Estrangeira. Brasília: Secretaria de Educação Fundamental (MEC/SEF).

Ministério da Educação. (2006). Linguagens, códigos e suas tecnologias. Orientações curriculares para o Ensino Médio, vol.1. Brasília: Secretaria de Educação Básica MEC/SEB).

Nogueira, M. A. (2017). Quando a meritocracia se vê ameaçada, o que ocorre com os padrões (históricos) da excelência escolar? In L. L. Torres \& J. A. Palhares (Eds.), A excelência académica na escola pública portuguesa (pp. 228-235). Vila Nova de Gaia: Fundação Manuel Leão.

Portaria $n^{\circ}$ 1322/07. (2007). Define carga horária de língua estrangeira. Diário da República, $1^{a}$ série, 192, 7107-7123.

Quijano, A. (2002). Colonialidade, poder, globalização e democracia. Novos Rumos, 37(17), 4-28.

Santos, B. de S. (2009). Para além do pensamento abissal: das linhas globais a uma ecologia dos saberes. In B. de S. Santos \& M. P. Meneses (Eds.), Epistemologias do Sul (pp. 23-71). Coimbra: Almedina/CES.

Santos, E. \& Schor, P. (2013). Brasil, estudos pós-coloniais e contracorrentes análogas: entrevista com Ella Shohat e Robert Stam. Estudos Feministas, 21(2), 701-725. DOI: 10.1590/S0104-026X2013000200020

Silva-Júnior, J. dos R. (2017). The new Brazilian university. A busca por resultados comercializáveis: para quem? Bauru: Canal 6.

Sousa, H., Marôco, J., Sampaio, M. M., Simões, P., Pereira, S. \& Castanheira, T. (2014). Teste key for schools. Resultados 2014. Sumário executivo. Lisboa: Instituto de Avaliação Educativa (IAVE)/MEC.

Spears, E. (2014). O valor de um intercâmbio: mobilidade estudantil brasileira, bilateralismo \& internacionalização da educação. Revista Eletrônica de Educação, 8(1), 151-163. DOI: $10.14244 / 198271991026$

Spivak, G. C. (1988). Can the subaltern speak? In C. Nelson, L. Grossberg, C. Nelson \& L. Grossberg (Eds.), Marxism and the interpretation of culture (pp. 271-313). Urbana; Chicago: University of Illinois Press. 
Unesco. (2000). Science for the twenty-first century. A new commitment. Declaration on sciense and the use of scientific knowledge. Science agenda-framework for action. Retrieved from http://unesdoc.unesco.org/ images/0012/001229/122938eo.pdf

Unesco Institute of Statistics (2018). Global flow of tertiary-level students. Retrieved from http://uis.unesco. org/en/uis-student-flow

Viana, C. (2018, March 25). Greve também é sinónimo de universidade? No Reino Unido, sim. Público, pp. $14^{-15}$

\section{BIOGRAPHICAL NOTES}

Rovênia Borges is a Ph.D. student in Education Sciences (Educational Policy) and a researcher at the Centre for Research in Education of the Institute of Education at the University of Minho, Portugal. She holds a Master's degree in Education and a Bachelor's degree in Communication Studies/Journalism from the University of Brasília, Brazil.

ORCID: https://orcid.org/oooo-0001-8259-5623

Email: roveniaa@gmail.com

Address: Ministério da Educação, Bloco L, Edifício-Sede, Sala 903, Esplanada dos Ministérios, 70047-900, Brasília, DF, Brazil

Almerindo Afonso is a sociologist, Ph.D. in Education, Associate Professor in the Department of Social Sciences and Education, and researcher at the Centre for Research in Education of the University of Minho, Portugal.

ORCID: http://orcid.org/oooo-0001-9879-5814

Email: ajafonso@ie.uminho.pt

Address: Instituto de Educação, Universidade do Minho, Campus de Gualtar, 4710057, Braga, Portugal

\section{* Submitted: 14.05.2018}

* Accepted: 12.07.2018 